
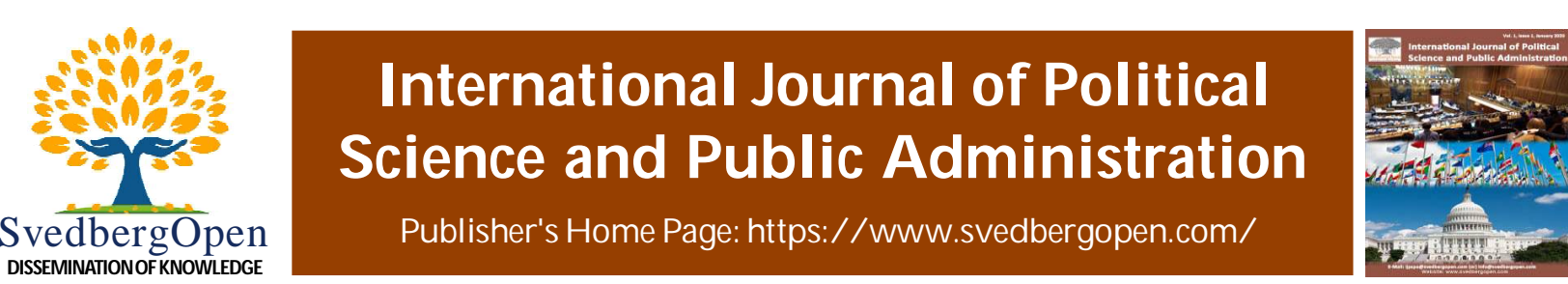

Research Paper

Open A ccess

\title{
An examination on challenges of political participation in rural Ethiopia
}

\author{
Mosaib Ahmad ${ }^{1 *}$ and Yihenew Misrak ${ }^{2}$ \\ ${ }^{1}$ Assistant Professor, Department of Political Science, Aligarh Muslim University, Aligarh, India. E-mail: mosaibahmad@gmail.com \\ ${ }^{2}$ Lecturer, Department of Governance and Development Studies, Bahirdar University, Bahirdar, Ethiopia. E-mail: yemisrak24@gmail.com
}

Article Info

Volume 1, Issue 1, June 2021

Received : 18 December 2020

Accepted : 25 April 2021

Published : 05 June 2021

doi: 10.51483/IJPSPA.1.1.2021.19-25

\begin{abstract}
Political participation entails a broad range of activities through which people express their opinion and try to take part in shaping of decisions that affect their lives. It is necessary for stable political system and consolidation of democracy. The purpose of this study was to examine the challenges political participation in rural Ethiopia. The research employed qualitative methods to collect and analyze data. Both primary and secondary sources of data were used. Whereas primary sources of data were collected through interviews secondary sources were obtained from the analysis of related literatures. The study found out that the challenges that impede people's access to political participation were related with personal, socio-cultural, and political factors. Accordingly, low political knowledge and skill, political inefficacy, time restraints, lack of political motivations, trust deficit, weak opposition political parties and absence of freedom were fond as main challenges that reduces political participation of rural people that have contributed for the undermined political development and democracy in the country.

Keywords: Challenges, Political participation, Rural Ethiopia

(C) 2021 International Journal of Political Science and Public Administration. This is an open access article under the CC BY license (https://creativecommons.org/licenses/by/4.0/), which permits unrestricted use, distribution, and reproduction in any medium, provided you give appropriate credit to the original author(s) and the source, provide a link to the Creative Commons license, and indicate if changes were made.
\end{abstract}

\section{Introduction}

The concept of political participation has been an interesting area research for academicians (Lamprianou, 2013). It entails a broad range of activities through which people express their opinion in the world and try to participate in shaping of decisions that affect their lives (Shimels, 2011).Political participation is citizens' legal actions that are more or less directly aimed at influencing the selection of government personnel and their actions. It also indicates the participation in the process of formulation, passage and implementation of public policies (Verba and Nie, 1972). According to the US Government and Politics Study Guide (2015), the concept of political participation refers to all actions which are intended to shape and affect the overall political spheres, ranging from voting to large political meetings to involving in the act of terrorism to sending a letter to representatives.

For many years, particularly until 1930s, voting was considered as the main tool for citizens' to make their voices heard in politics because many researches on citizens' political participation have conventionally focused on electoral participations (Gabriel et al., 2012). However, political participation is more than participating in election and sometimes the act of voting is not a necessary condition to identify a person involved in politics (Gabrielet al., 2012; Quaranta, 2012).

\footnotetext{
* Corresponding author: Mosaib Ahmad, Assistant Professor, Department of Political Science, Aligarh Muslim University, Aligarh, India.E-mail: mosaibahmad@gmail.com
} 
It includes a range of activities including unpaid campaign works, debating on political issues, attending political meetings, joining political groups, participating in boycott activities, strikes and demonstrations, and writing letters to representatives (Alesina and Giuliano, 2009). Political participation could be also demonstrated in electoral process, holding offices at the executive branch of government, joining associations and political parties, equal access to public services, freedom of expression and assembly, peaceful demonstration, referendums and contributing in policy and decision-making processes (Falade, 2015).

Verba and Nie (1972) used four dimensions of political participation as voting; campaign activities, contacting public officials and cooperative or communal activities and associates. Political participation may also be classified as electoral; consumer; party activities; protest activities and contact activities (Ekman and Amna, 2012); as electoral and non-electoral activities (Brady, 2003); as conventional, unconventional, and illegal activities (Quaranta, 2012; US Government and Politics Study Guide, 2015); as active and passive forms (Justis, 2002) or manifest and latent forms of participation (Ekman and Amna, 2012).

Citizens' participation is at the heart of democracy where democracy is unthinkable without citizens' ability to participate in the process of governing freely (Verba et al., 1995). Unless people in political processes are actively participated, democracy lacks both its legitimacy and its guiding force (Dalton, 2000). A competitive political system that allows citizens' participation leads to exercise political democracy in its full range. Hence, any claim to democratic regime must essentially embrace a high degree of competitive choice, openness, and enjoyment of civic and political liberties that involves all groups of the society (Falade, 2015). Political participation is essential for stable political system and enable citizens to have an opportunity to communicate with government officials on various issues (Ekman and Amna, 2012). Participation enables citizens to have more trust on the democratic system, to generate greater public satisfaction with democracy and to understand the mechanisms of democracy (Samiei and Reza, 2011). Political participation can increase citizens' knowledge and competence about the nature of political process and their own rights as citizens. Generally, individual's engagement in political activities have an impact on the content of government policies and affect individual life satisfaction and happiness (Shapiro and Winters, 2008).

Countries of the world have adopted a particular way of development in political participation depending on a range of factors such as historical inheritance, socioeconomic, cultural and political developments, and pressure from international actors (Heras, 2011; Lamprianou, 2013). People's political participation can be influenced by political motivations, social statuses, personal characteristics, and political environments (Samiei and Reza, 2011); by resources such as time, money, and civic skills (Bergstrom, 2006), by gender, level of education, and age (Lamprianou, 2013; Schulz, 2005). In everyday life, due to various factors, some individuals might actively participate in any forms of political activities, while others may wish to be observers (Heras, 2011). Therefore, the aim of this study was examining the main challenges that hinder rural people's political participation in Ethiopia.

\section{An overview of legal contexts on political participation in Ethiopia}

The 1931 Ethiopian constitution provides people certain rights to exercise political participations. The right to present petitions to the government within legal forms was recognized in chapter III. Chapter IV of the constitution also stated that provisionally, and until that time when the people are in a position to elect among themselves, the members of the chamber of deputies shall be chosen from among the dignitaries and from the local chiefs (Ethiopian Constitution, 1931). The1955-revised constitution provides the right to undertake peaceful assembly and to present petition for the emperor in accordance to conditions prescribed by law. It also allows all Ethiopian subjects to vote in the election of members of chambers of deputies under fulfilling the stated conditions (Ethiopian Constitution, 1955).

The 1987 Ethiopian constitution states citizens' equal participation in political, social, economic, and cultural activities. It also guaranteed freedom of press, speech, assembly, peaceful demonstration and association, the right to elect and to be elected, and the right to present criticism and complaints (PDRE Constitution, 1987). The transitional charter provides individuals the right to freedom of conscience, expression, association, assembly, the right to engage in unrestricted political activities and to organize political parties.

The 1995 FDRE constitution in chapter III guaranteed democratic rights such as the right to hold opinions, freedom of expression, press, association, the right to assemble, peaceful demonstration and the right to petition. It also guaranteed citizens' rights to vote and to be elected, participate in the conduct of public affairs directly and through freely chosen representatives; and the right to be a member of political organization and other associations (FDRE Constitution, 1995). 


\section{Methods}

The study has employed a qualitative approach which helps to address research questions that require explanation and to understand social phenomena in their contexts. Both primary and secondary sources of data were used to achieve the intended objective. Primary sources of data were collected through interview which was held with experts, political party leaders and public officials. Participants of the study were selected based on non-probability purposive sampling technique which helps to identify and select participants having rich information and better experience concerning the problem under study. On the other hand, secondary sources of data were obtained through the analysis of literatures. The collected data were analyzed thematically.

\section{Results and discussion}

The study showed that the challenges that affect people's political participation of people were grouped in to three major themes as personal, sociocultural and political. The effects such challenges on individuals' political participation however were not mutually exclusive but interrelated with each other. Countries' political, socioeconomic and cultural contexts largely determine the opportunities to engage in governance and other political activities (Kassa, 2015).

\section{Personal challenges}

Personal challenges are attributes of individuals that hamper their political participations. Regarding to this, actionoriented theoretical approach of social movements illustrated that there are various personal qualities and characteristics that trigger the political participation of individuals. Physical capitals like time; and human capitals such as education, knowledge and skills are enablers to participate in politics (Bergstrom, 2006; Verba et al., 1995). Accordingly the main personal challenges of political participation were discussed as follows:

Political knowledge (knowing about what and why political participation), and political skills (knowing how and when to participate) have an impact on people's political participation. Regarding to this, Lamprianou (2013) and Schulz (2005) indicated that education is an important factor that enables people to participate in political activities. Accordingly, the study found that lack of knowledge and skills about politics was one of the problem that rural people encountered. Many people are not fully aware how they can exercise their political rights (how can they vote, why they should vote, what they should speak in meetings, and why they should participate in demonstrations and other activities). Some were notable to identify desirable and undesirable political activity for them. The following interview is important to look at this fact.

Many individuals have participated in political activities without knowing the role of their participations. They do not ask themselves why and when they should participate in political activities. Moreover, some have isolated themselves from participating in political activities without sufficient reasons (Interviewee 08, 2020).

The study showed that due to lack of political knowledge many individuals were unable to evaluate the action of government rationally. Because of their misunderstandings, some individuals equated political participation as participating in corruption, being servant for others, being medium of information and other socially unaccepted activities. If a person does not understood what political participation means, and what its role is, it is more unlikely for him/her to participate in it. They externalize political participation from daily activities and thought political issues are left to political leaders, party members, and other educated individuals. In line with this, Kluienko (2007). Political participation has strong positive relation with level of education where educated people accept political issues as political by answering them politically and proceeding from purely political principles. Similarly, Wolpe (2007) maintained that lack of understanding of political issues (ignorant) challenges individuals' political participations. Generally, participants of the study faced problems of political skill and knowledge to understand what politics and political participations mean, who participated, how they could participate, and why they have participated in political activities.

The study indicated that many household activities and burdens caused rural people to give less emphasis for political issues. Time is an important resource for people to participate in political activities (Verba et al., 1995; Bergstrom, 2006). Participants stated that people in rural areas always think how they can educate their children and how they can improve their economic and social life than worried about who rules and how government functions. They thought that the political participation consume their time and should not considered as part their life. Generally, the study showed that due to time constraints participants gave more emphasis for their personal and societal activities than politics as they thought that political activities weaken their economic and social life. 
Another personal challenge that weakens political participation of people in rural areas was feeling of low political efficacy. The study showed that many people in rural areas felt that their involvement in political activities would not affect political process. They thought that they were unable to bring any political and social changes through political participation. One participant stated that: "many individuals looked their political participations as fruitless. Many of them considered that their political participation is wastage of time that could not change the political fate of the state" (Interviewee 02, 2020).

The statement by the above participant indicated that if people feel that they will not get anything and cannot bring any change through participation, they will become reluctant to participate. Regarding to the effects of political efficacy, $\mathrm{Li}$ and Marsh (2008) stated that political participation is related to individuals' political efficacy. Individuals who lack the quality of political effectiveness are less participants in political activities (Bergstrom, 2006). Similarly, Chakraborty (2005) and the US Government and Politics Study Guide (2015) illustrated that if individuals feel no one in power listens to their views and government is at best indifferent to them, they become less participants in political activities.

Political motivation based on people's idea about the essentiality of participation and feeling of involvement (political self-consciousness - the sense of civic duty to participate) is important for political participation (Kluienko, 2007). Moreover, proponents of civic volunteerism model argued that people must have a certain level of motivation to be participant in political activities (Rubenson, 2000). Accordingly, this study found that individuals' low level of motivation was the other challenge on political participation. Interviewee 03 (2020) said that:

It is through several efforts that rural people come in to political activities. Due to low political motivation of individuals' sometimes we have to compel theme to participate in public meetings, and demonstrations. It is common to bring people in to participation through high provocations, persuasions, and impositions.

From this explanation, it is clear to understand that people low level of political motivation affects their participation in political activities. Regarding to this, Eremenko (2010) explained that political participation depends on how the people think and take the responsibility to be active. That means, do they really want to participate or they are indifferent. Alternatively, do they have life philosophy to fight for their rights and views or not. Falade (2015) and Schulz (2005) also illustrated that individuals commitment can determine their political participations.

\section{Sociocultural challenges}

The study found that the other challenge that affects people's participation in politics is their backward attitude towards politics. The study showed that many individuals in rural areas were hated political issues blindly. There was a common saying: "do not touch politics" or "better keep distance from politics and electricity" in the society. This dictum reminds people to fear and hate political participations. In addition, the study revealed that individuals who are actively participated in political activities have been seen as idle and have no care for their families. Political participation is seen as something which is profligate. Some have thought that political participation is the duty of government officials and educated individuals. In this regard, Agbalajobi (2010), Nwabunkeonye (2014) and Endale (2014) indicated that backward attitudes negatively affect individuals' involvement in political activities. In view of this, the study showed that poor and backward political opinions significantly hinders people's political participation.

The study also indicated that trust deficit among the people was the other factor that weakens individuals political participation. The study showed mistrust and insincerity among the society influences their free participation in political activities. Interviewee10 (2020) stated that:

Many individuals are not interested to discuss political issues with anyone. They do not freely express their political feelings and stands in public forums. Many of them assumed that government secrete agents who follow the daily activities of the society will report their political opinion to local officials whoin turn harms them in various maladministration practices.

The above statement demonstrated that because of trust deficit, individuals were not confident to talk about political issues with their friends, they did not express their opinions and ideas in public meetings, they did not express their political stands in front of people, they could not openly support political parties, and they were not free to criticize local officials.

\section{Political factors}

Political system is a key factor that determined people's political participation (Samiei and Reza, 2011). Political conditions like the nature of political system, party system, electoral system, institutional arrangements, efficiency and effectiveness of government and nature of political culture determine political participation (Chakraborty, 2005). Furthermore, structural 
approach of social movement argued that political opportunities highly determine the success and failure of social movements. Political system make easy or complicate people's ability to gain access to political system (Bergstrom, 2006).

Accordingly, the study revealed that the low outreach of opposition political parties is one of the challenge that constrained people's political participation in rural areas. Political parties are the main agents and tools for citizens' political participation where their existence for a long period enables people to be familiar with political system. Political parties educate people about the overall political system and encourage them to participate in various political activities. Gudeta and Alemu (2014) also illustrated that strong and sustainable democratic governance depends on the wellfunctioning of opposition political parties. Political parties bringing diverse interests together, recruiting and presenting candidates, and developing competing policy proposals that provide people with a choice (Chege et al., 2007). Regardless of political parties have such roles, they were unable to reach to the rural areas in the full range.

Concerning to the statuses of political parties in Africa, Chege et al. (2007) asserted that political parties have faced challenge like unacceptability and distrusted, declining membership, and weak and undemocratic internal management. They are either too small in terms of total membership to have any electoral effect, or are registered in the books but moribund (Chege et al., 2007). Kassahun (2009) confirmed that meaningful participation of opposition political parties in the political process has been largely inadequate which greatly undermined the process of the Ethiopian democratization process. One of the participants stated that: "the activities of opposition parties are urban centric where their existence in the rural areas is informal, hidden, and secret. People were not aware enough about the programs of opposition parties" (interviewee 01.2020).

Therefore, rural people's participation in the activities of opposition political parties were rare since parties are not accessible to the people. In this regarded, EU (2010) affirmed that throughout Ethiopia, the ruling party is unrivalled by opposition parties especially in the rural areas. Kassahun (2009) explained that Ethiopian opposition parties are handicapped in various ways where their operation is limited in the capital city and few major urban centers due to pressures and threats from local government officials. Likewise, Gudeta and Alemu (2014) asserted that in Ethiopia, opposition parties have inadequate link to the society particularly in the rural community. Generally, opposition political parties have not outreached to the rural area which in turn reduces people's political participation.

The study also showed that the political participation of people in rural area is constrained by absence of freedom. Participants explained that people in rural areas were free to participate in political activities only when local officials allow them to do so. People were not free to involve in any political movements against the interest of local leaders. They were not free to be members of opposition political parties and to show their oppositions through demonstration and riots. Eremenko (2010) argued that looking at institutional design (originally democratic, being under reformation or democracy) is important factor in citizens' level of political participation. The following participant illustrated this fact in that:

Participating in any political activities other than allowed by local officials is considered as a crime, anti-peace, antidemocracy and gave other bad names in the society. Individuals who are involved in any opposition political activities were at risk in various maladministration. Hence, many individuals preferred to abstain themselves from any political involvements (Interviewee 07, 2020).

From this expression, we can understand that due to absence of freedom leaders, intimidation and harmful administration practices, people were not free to participate in various political activities. In line with this, a study by Nwabunkeonye (2014) and Wolpe (2007) demonstrated that undeveloped democratic culture and unhealthy political is means to weaken citizens' active participation in political activities. In view of this, study found that lack of freedom which was a function of unhealthy political environment prevents people from participating in different political activities. Local officials did not encourage people to participate in political activities unless they need their participation for the purpose of their own.

A study Endale (2014) and Eyob (2009) indicated the low political involvement of people in Ethiopia is partly related with commercialization of the political process and low commitments of concerned top decision makers. According to mobilization model of political participation, individual participate in political activities in response to the political opportunities and stimuli from other people. People remain outside of the recruitment networks, which bring them in to political participation if no one ask and encourage them to do political activities (Verba et al., 1995).

\section{Conclusion}

This study was about the challenges of political participation of the people in the rural areas. Accordingly, the study revealed challenges in to three categories which can be enlisted as personal, sociocultural, and challenges related with 
lack of conducive political environments. Accordingly, lack of political knowledge and skill, time constraints, political inefficacy, and low level of political motivations are found to be personal challenges that hinders people's political participation. On the other hand, the sociocultural challenges include poor opinion towards political participations and trust deficit between people.

To end with, the study demonstrated that weak performances of opposition political parties, absence of freedom and government's low emphasis to improve people's political participation are challenges resulted from underdeveloped and undemocratic political environment. Such challenges of political participation severely affect people's political participation. In the absence of proper measures to address these challenges, people will remain ignorant and excluded from political activities which in turn adversely affect political development and consolidation of democracy.

\section{References}

Agbalajobi, T. (2010). Women's participation and the political process in Nigeria: Problems and prospects. African Journal of Political Science and International Relations 4(2), 075-082.

Alesina, A. and Giuliano, P. (2009). Family ties and political participation, Harvard Institute of Economic Research (No. 2171). Discussion Paper.

Bergstrom, L. (2006). Political participation: A qualitative study of citizens in Hong Kong.

Chakraborty, S. (2005). Political sociology, Macmillan India Ltd. New Delhi.

Chege, M. (2007). Political parties in East Africa: Diversity in political party systems. International IDEA. Stockholm, Sweden.

Ekman, J. and Amna, E. (2012). Political participation and civic engagement: Towards a new typology. Human Affairs 22(3), 283-300.

Endale, Alemu. (2014). Factors that affect Women Participation in leadership and decision making position in in Bedele town administration, Asian Journal of Humanity, Art and Literature, 1(2).

Eremenko, M. (2010). Political participation: Model by Verba in the EU and Russia.National Research University.

European Union Election Observation Mission to Ethiopia (2010). Ethiopia final report house of people's representatives ad state council election.

Eyob, Balcha. (2009). Youth and politics in the post 1974 Ethiopia: intergenerational analysis, International Institute of Social Studies, Hague: Netherland.

Falade, D.A. (2015). Political participation in Nigerian democracy: A study of some selected local government areas in Ondo state, Nigeria, Global Journal of Human-Social Science Research, 14(8).

Gabriel, O., Keil, S.I. and Kerrouche, E. (2012). Political participation in France and Germany, traditions, concepts, measurements, patterns and explanations. Political Participation in France and Germany

Gudeta, Kebede. and Alemu, Kassa. (2014). Ethiopian opposition political parties in the post-1991 political structure, published online.

Heras, G.L. (2011). Political participation in Mexico (1988-2009): How and why has it changed. Inter-American Development Bank, Research Department, RES Working Papers, 638, 52.

Justis, T. (2002). Political participation trends of yesterday and today, Unpublished.

Kassa, Shimels. (2015). Challenges and opportunities of women political participation in Ethiopia, Journal of Glob Economy. 3(162), 2.

Kassahun, Berhanu. (2009). Ethiopia: Beleaguered opposition under a Dominant Party System. Addis Ababa University, Unpublished.

Kluienko, E. (2007). Political participation: theory, methodology, and measurement with the help of the Guttman OneDimension Continuity Scale, Ukrainian Sociological Review. 4, 122-154. Retrieved from: http:// nbnresolving.de/urn:nbn:de:0168-ssoar-105912.

Lamprianou, I. (2013). Contemporary political participation research: A critical assessment. In Democracy in transition Springer. Berlin Heidelberg. 21-42.

Li, Y. and Marsh, D. (2008). New forms of political participation: Searching forexpert citizens and everyday makers, British Journal of Political Science, 38(02), 247-272. 
Nwabunkeonye, U. (2014). Challenges to women active participation in politics in Nigeria, Sociology and Anthropology. 2(7), 284-290.

Quaranta, M. (2012). The rise of unconventional political participation in Italy: Measurement equivalence and trends over time. 1976-2009. Bulletin of Italian Politics. 4(2), 1976-2009.

Samiei, N. and Reza, M. (2011). Political participation and government size. Canadian Social Science, 7(2), 224-235, Published Online.

Schulz, W. (2005). Political efficacy and expected political participation among lower and upper secondary students, a comparative analysis with data from the IEA civic education study, Australian Council for Educational Research. Online Submission.

Shapiro, R. and Winters, M. (2008). Political Participation and Quality of Life.

Shimels, Sisay. (2011). Electoral participation as a fundamental political right of persons with disabilities in Ethiopia: critical examination of the law and the practice. (Doctoral Dissertation, Addis Ababa University).

Verba, S. and Nie, N. (1972). Participation in America: Political democracy and social equality. Harper and Row publishers, New York.

Verba, S., Schlozman, K.L. and E. Brady, H.E. (1995). Voice and equality: civic voluntarism in American politics. Cambridge, MA: Harvard University Press. (4).

Wolpe, H. (2007). Youth and politics in conflict context, project on leadership and building state capacity. Woodrow Wilson International Center for Scholars.

Cite this article as: M osai b A hmad and Yihenew Misrak (2021). A n exami nation on chal lenges of political participation in rural Ethiopia. International Journal of Political Science and Public A dministration. 1(1), 19-25. doi: 10.51483/ IJPSPA.1.1.2021.19-25. 